Available online at http://journal.ugm.ac.id/jifnp DOI: http://doi.org/10.22146/ifnp.33423
INDONESIAN FOOD AND NUTRITION PROCRESS

Indonesian Food and Nutrition Progress, 2018, Vol. 15, Issue 2

\title{
Probiotic (Lactobacillus casei) Encapsulation Using the Method of Spray Drying with Combined Prebiotic from lles-lles (Amorphopallus oncophyllus) and Protectant Agent (Skim Milk, Gum Arabic, Maltodextrin)
}

Aloysius Prima Cahya, Meidi Syaflan*), Ngatirah

\author{
Department of Agricultural Product Technology, Faculty of Agricultural Technology, \\ Institut Pertanian Stiper, Yogyakarta \\ ${ }^{*}$ Corresponding author, email address: meidi_syaflan@yahoo.com
}

\begin{abstract}
The aims of this research were to know the effect of combine iles-iles (refined starch, whole iles-iles flour, and refined glucomannan) as encapsulating agent (capsule materials) and different protectant agents to get microcapsule synbiotic, which have the highest number of probiotic cells and high viability against low $\mathrm{pH}$ and bile salt. Design blocks complete with factorial design was used in the experimental design. The first factor was capsule materials with a concentration of $10 \%$ consisting of three material types: A1 (refined glucomannan), A2 (refined starch), and A3 (Iles-iles native). The second factor was protectant, protecting the probiotic bacteria during spray drying, used at concentration of $5 \%$ consisting of three substances i.e. B1 (skim milk), B2 (maltodextrin), and B3 (gum arabic). Using protectant agents on the MRS for the growth of L. casei resulted no effects against the numbers of LAB (lactic acid bacteria), density, moisture content, and hygroscopicity; however, it had influence on yield and solubility. The best use based on the reduction of LAB numbers were flour and gum Arabic which was significant compared to other fractions.
\end{abstract}

Keywords: iles-iles, glucomannan, starch, protectant agent, symbiotic LAB

\section{Introduction}

lles-iles (Amorphophallus spp.) is a plant member of araceae family. The plant has a stem reached height of about 1-2.5 $\mathrm{m}$. It has a life cycle of about 4-6 years and produces 5-10 bulbs in every season of its planting. Various species grow in East and Southeast Asia regions, such as $A$. konjac $k$. Koch, $A$. rivierii, $A$. oncophyllus, A. bulbifer etc. (Takigami, 2000). However, in Indonesia the existing varieties are A. oncophyllus prain and $A$. variabilis $\mathrm{BI}$. The Amorphophallus Spp.'s bulbs obtained from $A$. oncophyllus prain in Indonesia is known as lles- iles which has been widely used as raw material in flour industry (Kay, 1987).

lles-iles contains prebiotic namely flour native, starch, and glucomannan (Takagami, 2000). Each fraction of iles-iles components has different properties which determine its ability to form a gel. Glucomannan works well as a thickning agent owing to its great water absorption capacity ( $\geq 100$ times fold higher than its own weight) and great molecular weight. Glucomanan was reported to have the highest molecular weight among the other fibers. In addition to glucomannan, starch and 
properties have capabilities high swelling power. Starch is composed of small granules. When starch is incorporated into cold water, the starch granules absorb water and swell. However, the amount of water absorbed is limited to $30 \%-w / w$. Similarly, when the starch granules are heated in water, it begins to inflate (swelling).

lles-iles flour contains high glucomannan level which reached up to $64.98 \%$. Glucomannan has - $\mathrm{OH}$ group which is able to form hydrogen bridges with water. Whole iles-iles flour has a complex structure. On native iles-iles, water is adsorbed quickly only at the surface and unable to penetrate into the granule flour. Besides its potential as prebiotic, capsule ingredients from iles-iles can be used as an encapsulating agent which protects probiotic bacteria cells from low $\mathrm{pH}$, extreme conditions, and bile salts.

According to Swaisgood (1991), the use of long chain hydrocoloid polymer with a high molecular weight for encapsulation could improve solubility and served as a thickener even a gelling agent. For materials used in spray drying encapsulation method, it must exhibit a high solubility and have the ability to form emulsion, film, and to dry out as well as to produce concentrated aqueous solution with a low viscosity.

In the present study, the encapsulation followed with spray drying was used to produce particle with size less than $1 \mathrm{~mm}$. The bigger the number of microcapsules generated, the easier the process to be accomplished or to be scaled up. The dissadvatage of spray drying method for encapsulation of probiotic/synbiotic is the low cell viability of $L A B$ due to the heat. The problem can be solved with addition of protectant such as gum Arabic, skim milk, maltodextrin which capable of protecting and maintaining the cell viability during spray drying (Chandra-mouli, 2003). Based on this reason, further research on the types of the material and the addition of protectant in the process of encapsulation by spray drying is needed.

The purpose of this research was to study the influence of iles-iles fractions (starch, flour, and glucomannan) as encapsulating agent (materials capsule) for Lactobacillus casei in synbiotic produced through spray drying method and thus, getting the best microcapsule synbiotic containing iles-iles which had the highest number of viable probiotic cells.

\section{Materials and Methods}

\section{Extraction of lles-lles Flour}

lles-iles tuber was brought from Sentolo, Kulonprogo Yogyakarta, harvested, weighed, peeled, and washed with water. Afterwards, the bulbs of iles-iles were sliced into thin cuts, soaked into a 1,500 ppm Na-Metabisulfit solution for 15 minutes, and drained for 15 minutes. The tubers were then dried under the sun $\left(55^{\circ} \mathrm{C}-60^{\circ} \mathrm{C}\right)$ for $48 \mathrm{~h}$. Afterwards, the dry tubers were milled and sifted to obtain particle size of 60 mesh (Safii, 1981).

\section{Extraction of Iles-Iles Starch}

The iles iles flour was weighed, followed by adding water into the flour at ratio of $10 \mathrm{~g}$ flour: $20 \mathrm{~mL}$ water. The mixture was then continuously filtered and squeezed out using a fabric filter (cheese cloth) to separate the filtrate from the residues. The filtrate was taken and stored in the room for $24 \mathrm{~h}$. This was then followed by drying in an oven at $\pm 40^{\circ} \mathrm{C}$ for 48 h. Finally the lles-iles starch was sifted through 100 mesh sieve. The starch obtained was then stored in a closed jar at room temperature (Hermansyah, 1985).

\section{L.casei Biomass Preparation}

For preparation and rejuvenation of the culture, L. casei cultures in MRS media was 
innoculated by 2 ose. The sample was then incubated at a temperature of $30^{\circ} \mathrm{C}-35^{\circ} \mathrm{C}$ for 24 hours. After 24 hours, the old L. casei was reinoculated for rejuvenation. Subsequently, the sample was incubated at $30^{\circ} \mathrm{C}-35^{\circ} \mathrm{C}$ for 24 $\mathrm{h}$ then bred in a $10 \mathrm{~mL}$ of sterile MRS broth. After that, incubation was conducted at a temperature of $30^{\circ} \mathrm{C}$ for $24 \mathrm{~h}$. The cultures were then sentrifuged for $20 \mathrm{~min}$ at 3,000 rpm. The pellet was collected to obtain $L$. casei biomass and stored in a refrigerator. Prior to the encapsulation, the biomass was suspended with $1 \mathrm{~mL}$ of sterile distilled water.

\section{Encapsulation Process by Spray Drying Method}

Iles-iles flour with a concentration of $10 \%$ ( $250 \mathrm{~mL}$ distilled water and $25 \mathrm{~g}$ ) was used for the encapsulation. The sample was fused with skim milk at $5 \%$ ( $250 \mathrm{~mL}$ distilled water and protectant type $12,5 \mathrm{~g}$ ), sterilized at 1 bar and cooled. Subsequently, L. casei biomass (pellets) suspended in distilled water was added, followed by Mixing the mixtures to obtain a homogeneous mixture.

The process of encapsulation by spray drying was then performed. The powder obtained was then weighted for yield evaluation and analyses.

\section{Analysis of The Amount of $L$. casei Bacteria (Jutono,1973)}

Dilution was performed using clean and sterile test tubes. The test tubes were filled with $9 \mathrm{~mL}$ of sterile distilled water. One mililitre of diluted materials was then added into the test tubes with micro pipette. A dillution series ranging from $10^{-1}$ to $10^{-8}$ was prepared. Total bacteria calculation was carried out using solution with dillution factor of $10^{-6}, 10^{-7}$ and $10^{-8} .1 \mathrm{~mL}$ each solution was taken and poured in a sterile petridish filled with $10 \mathrm{~mL}$ of PGY media (duplo). It was then followed by incubation for $48 \mathrm{~h}$ at $37^{\circ} \mathrm{C}$ in the reversed positions. The number of lactic acid bacteria colonies was calculated using hand counter.

\section{Analytical Calculation of Bulk Density}

Two $\mathrm{mL}$ of sample was placed into a measuring cup then vibrated for a minute. Bulk density is the proportion between mass with volume of the microcapsule after vibration. This method was adapted from Phoungchandang and the Sertwasana (2010).

$$
W_{0}=W_{2}-W_{1}
$$

where:

$W_{0}=$ Weight density

$W_{1}=$ Weights of emptied measuring cup

$W_{2}=$ Weight of the measuring cup + sample

\section{Analysis of Moisture Content}

Moisture content was determined according to the American Association of Cereal Chemists (St. Paul, MN, USA). One gram of powder/sample was placed in a container/aluminium foil and dried at a temperature of $105^{\circ} \mathrm{C}$ untill a constant weight has been reached. Residual moisture content was calculated by the formula:

$$
\% \text { moisture }=\frac{W_{f}-W_{i}}{W_{i}} \times 100 \%
$$

where

$W_{i}=$ Weight of dry probiotic formulations before dehydration at $105^{\circ} \mathrm{C}$

$W_{f}=$ Weight of dry probiotic formulations after dehydration at $105^{\circ} \mathrm{C}$

\section{Hygroscopicity Analysis}

The Hygroscopicity of the probiotic powder/sample was determined in accordance with the procedure outlined by Fritzen-Freire et al (2013). More specifically, one gram of sample was brought into a container whih was placed in a dessicator filled with saturated sodium chloride solution (75\%). The samples were then kept for 5 days at room 
temperature. The hygroscopicity of the sample was calculated using the following formula:

$$
\% \text { hygroscopicity }=\frac{m_{f}-m_{i}}{m_{i}} \times 100 \%
$$

where

\%hygroscopicity is measured in $\mathrm{g}_{2} \mathrm{O}$ per g product

$\mathrm{m}_{\mathrm{i}}=$ Moisture contents of the sample before storage at $75 \%$ humidity

$\mathrm{m}_{\mathrm{f}}=$ Moisture contents of the sample after storage at $75 \%$ humidity

\section{Particle Size Analysis}

The particle size of the microcapsule was measured using SEM (Scanning Electron Microscopy) by determining the average diameter.

\section{Statistical Analysis}

According to Ansel (2004), based on the density equation, mass and volume are strongly related. The relationship between mass and volume affected the compactness of a component. In terms of the protecting agent, maltodextrin had the highest yield. This occured because maltodextrin had higher molecular weight than skim milk or gum Arabic. Upon heating, when mixed with water, maltodextrin form a colloid system. Furthermore it can act as a thickening agent and encapsulation material. It was reported that the type of illes illes fractions and protecting agend did noot influence the density and diameter of the capsule. that the type of illes illes fractions and protecting agend did noot influence the density and diameter of the capsule.
Statistical analysis wasperformed using Complete Block Design test and DUNCAN test.

\section{Results and Discussion \\ Yield Analysis (Microcapsule Results)}

The results showed that the iles-iles fractions had no effects on the yield of the microcapsules while the influence of protectant material variation was described in Figure 1.

The capsule material prepared using native iles-iles produced the highest yield which could be attributed to eto the characteristics of the flour. Theflour has a fairly high density compared to other materials. In addition, the flour still contains glucomannan, starch and cellulose, thus it had a molecular weight and density resulting in a strong structure.

\section{The Amount of $L$. casei Bacteria Before-After} Spray Drying

The results of the analysis showed that the type of iles-iles fractions and protectant had an effect on the reduction of the number of bacteria during spray drying (Figure 2). The results showed that the amount of $L$. casei bacteria in microcapsule containing iles-iles flour and gum arabic as the protecting agent had the lowest cell number. This was mainly due to the fact that iles-iles flour contained glucomannan and starch which are rich in $-\mathrm{OH}$ group which is able to form hydrogen bonds with water. This type of flour has a complex structure. In the presence of water, water absorbed quickly only at the surface and unable to penetrate into the granule (Arifin, 2001). 


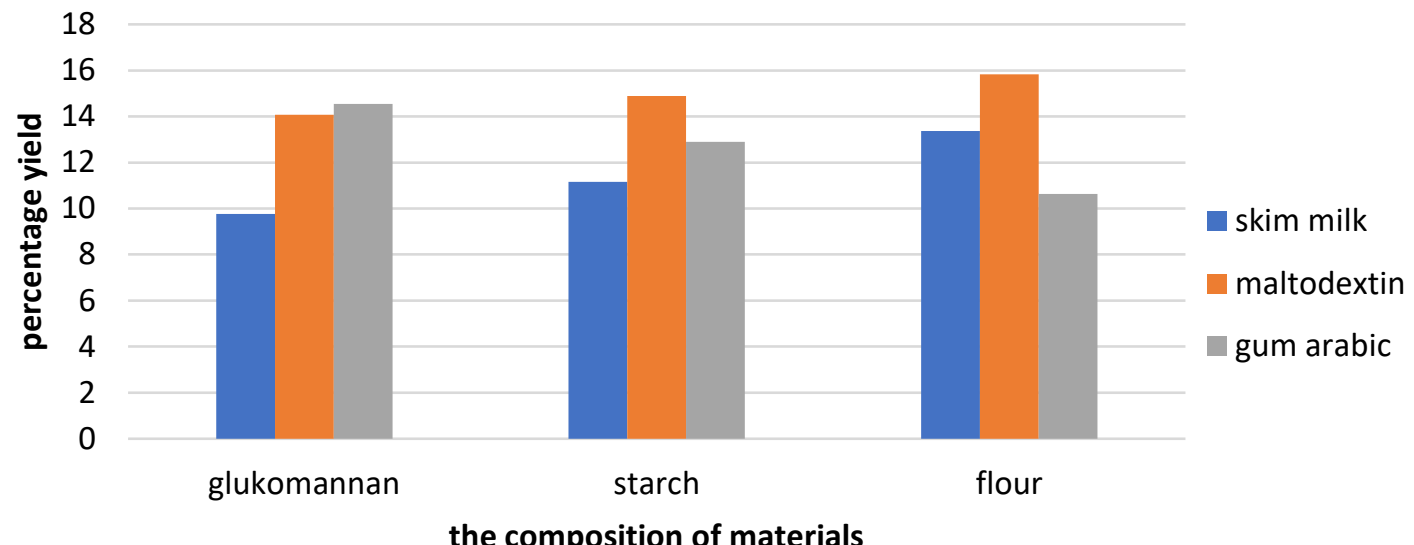

Figure 1. Microcapsule Synbiotic Yield (\%) affected by iles-iles fractions and protectant

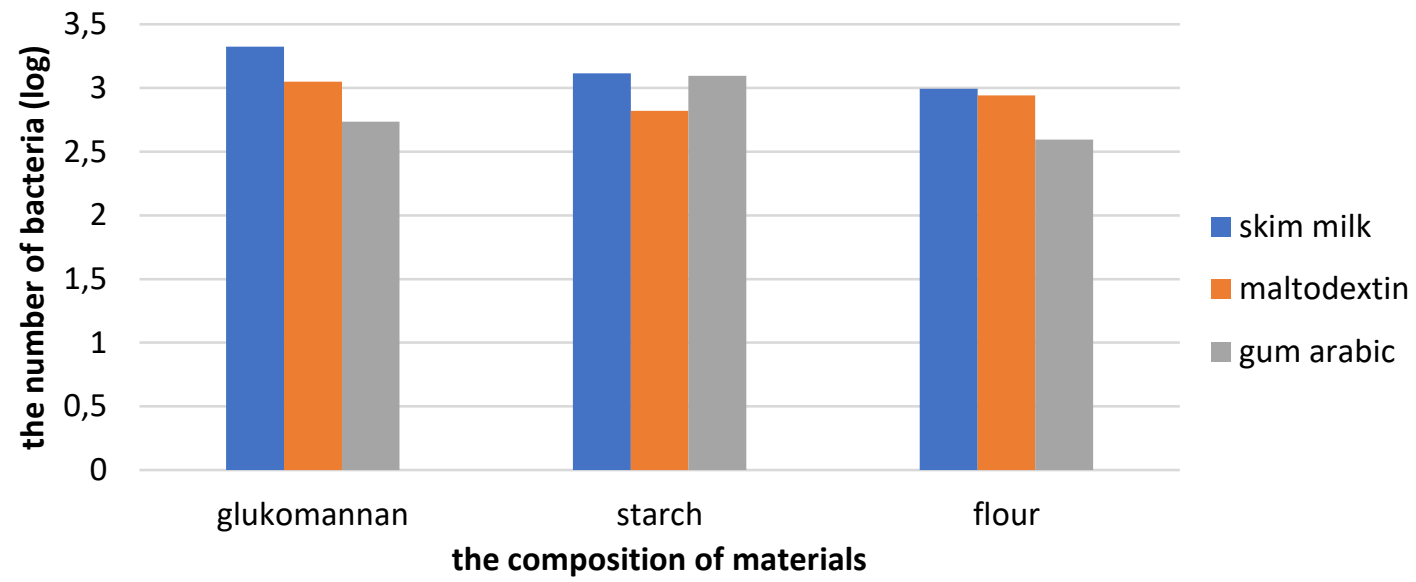

Figure 2. Logaritmic bacterial decrease due to spray drying

Gum Arabic can be used as the binding agent for flavor, as thickening, as well as film former of emulsion. Gum Arabic contains groups of arabinogalactan proteins (AGP) and glycoprotein (GP) which can act as emulsifier and thickener. Gum Arabic has unique properties due to its high solubility and low viscosity (Tranggono et al., 1991).

\section{Analysis of Bulk Density (Weight Density)}

The influence of type of iles-iles fractions and protectant on the specific gravity of bulk density was shown in Fig.ure 3. According to Ansel (2004), mass and volume are strongly related. Density is the ratio of mass to volume. For a constant mass, he greater the volume of a product, the smaller the density, and vice versa
The application of maltodextrin resulted in the highest bulk density value. This occured because maltodextrin had larger molecular weight.

\section{Diameter Capsule}

The diameter of the capsules was measured using methods of SEM (Scanning Electron Microscope) that is designed to study the surface of solid objects. SEM has a magnification of 10-300000x with a resolution of 1-10 nm (Goldstein, 2003). Capsule diameter analysis results can be seen in Figure 4.

Based on the results, the diameter of the microcapsule prepared with iles-iles flour had a large size which could be attributed to the high density and molecular weight of the iles 
iles flour. In addition, the iles-iles flour still contained glucomannan, starch, and cellulose so it has complex properties.

The diameter of microcapsule prepared with maltodextrin as the protecting agent had the biggest size. This occurred because maltodextrin was the residue of starch breakdown, and thus posses higher molecular weight than skim milk or gum Arabic.

\section{Analysis of Hygroscopic Properties}

The results of Hygroscopic analysis can be seen in Figure 5. Hygroscopic properties of a material are influenced by the absorption of water to the material. In Figure 5, it can be seen that the microcapsules containing glucomanan had a high hygrocopicity. Compared to the other materials, glucomanan works well as a thickening agent and has water absorption capacity of more than $100 x$ of its own weight (Takigami, 2000).

Similarly, the microcapsules containing skim milk also had the highest hygroscopicity. This was due to the fact that skim milk itself is very hygrocospict. Skim milk contains hygroscopic essential amino acids (Shortt, 1999).

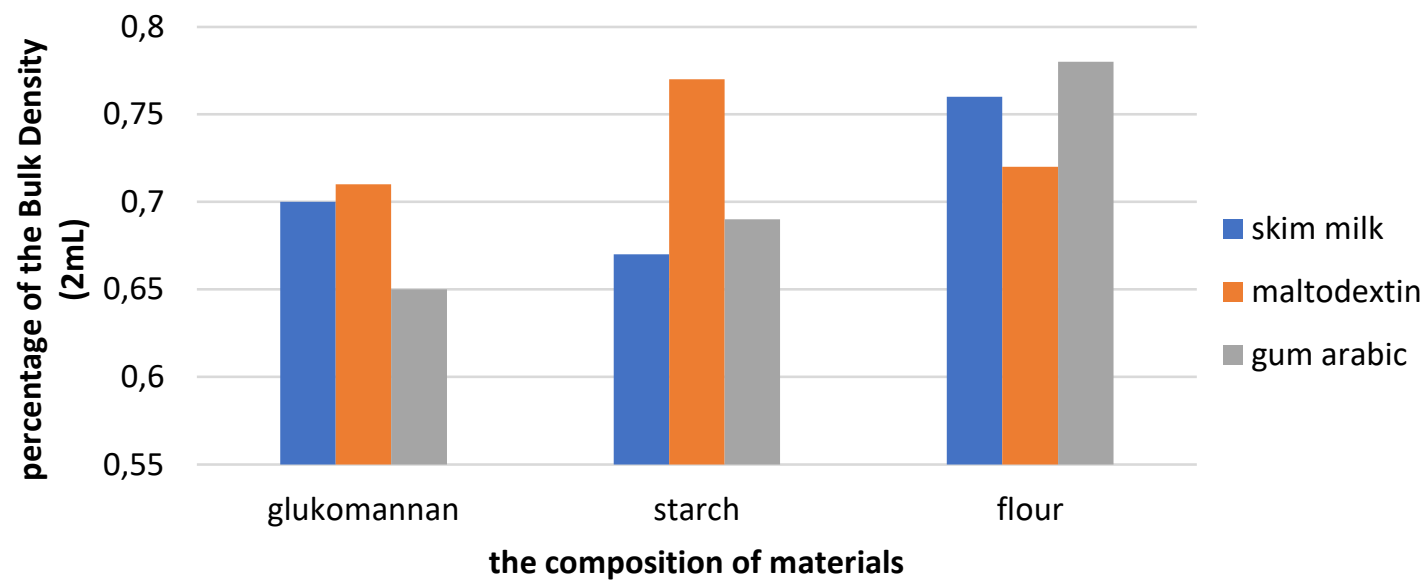

Figure 3. The results of bulk density analysis $(2 \mathrm{~mL})$

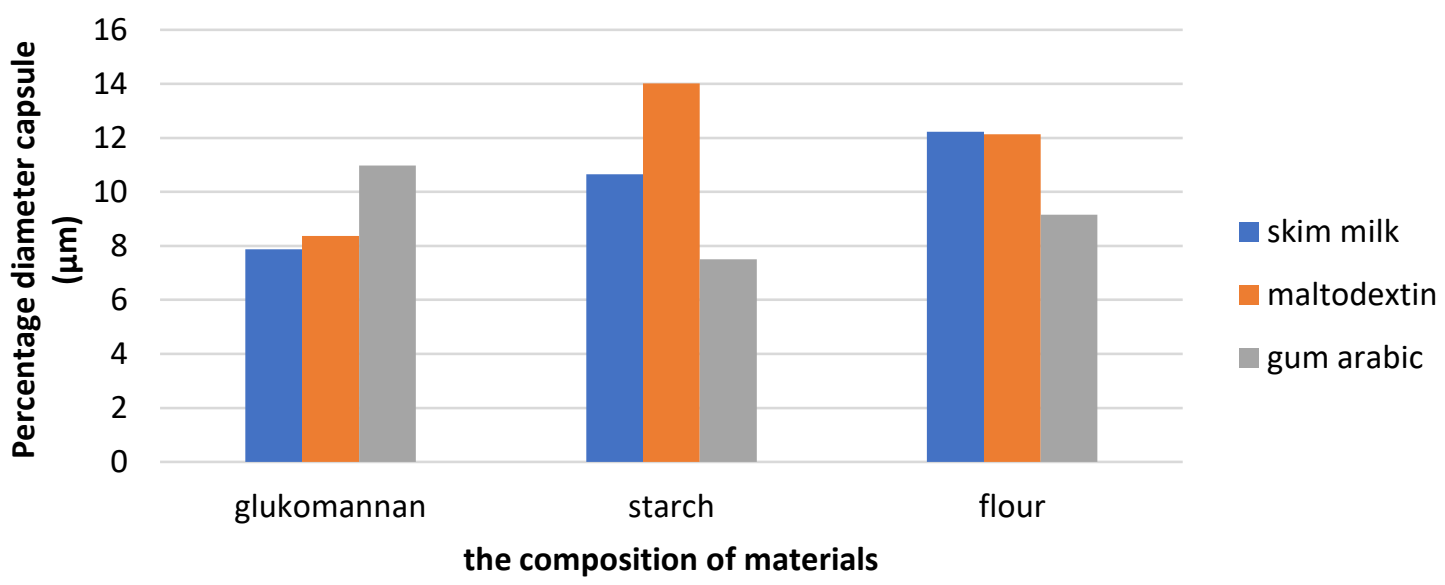

Figure 4. The results of capsule diameter analysis $(\mu \mathrm{m})$ 


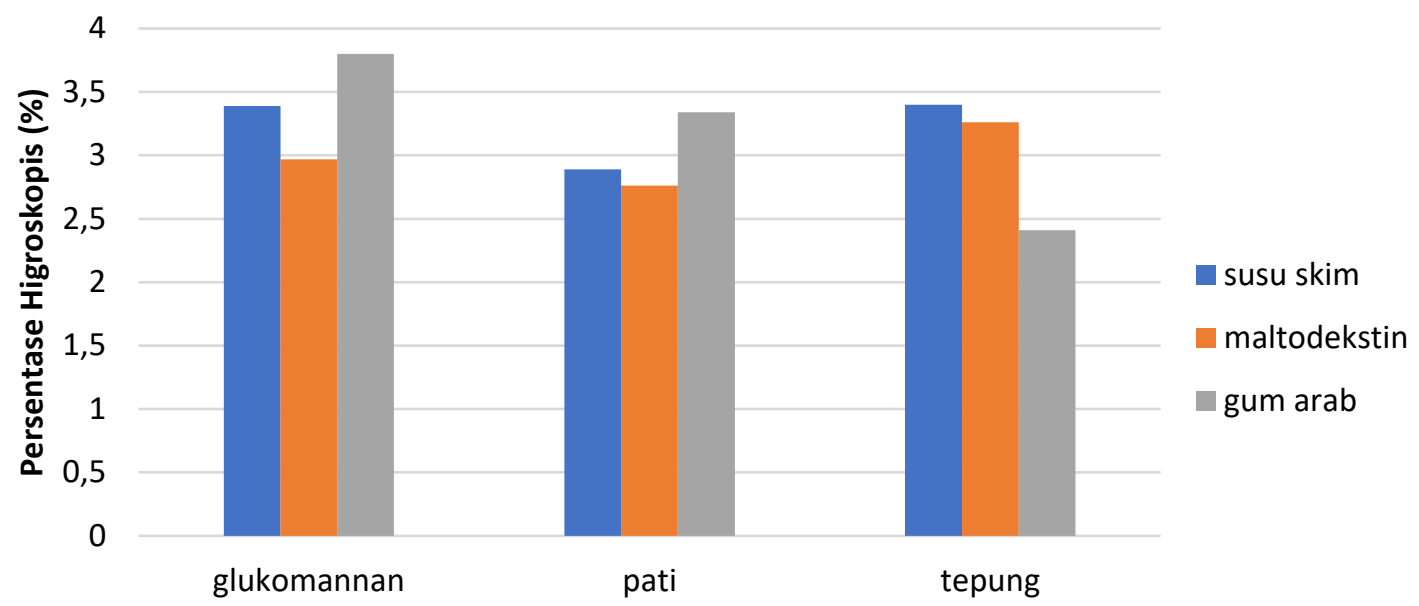

The Composition of materials

Figure 5. The results of hygroscopic analysis (\%)

Moisture Content Profile in Microcapsule

The results of the analysis showed that the type of iles iles fraction and protectant had no effect on the moisture content of the microcapsules as shown in Figure 6 . Nevertheless, it is worth to mention that microcapsules containing starch seemed to have the highest moisture content due to the presence of amylopectin and amylose.

Amylose and amylopectin levels affected the moisture content profile of the microcapsules. This happened because the amylopectin and amylose starch are composed of $\mathrm{OH}$ - cluster which are easily bound to water. Amylose has molecular weights ranging between 105-106, with a degree of polymerization of up to of 500-6000. The large number of hydroxyl groups contained in the glucose polymer compounds caused the amylose to have hydrophilic property. Amylopectin molecule is a polysaccharide with a highly branched structure. Amylopectin contains glucose unit linked through $\alpha-1.4-$ glycosidic linkage, while $\alpha-1.6$-glycosidic linkage can be found on the branch. It has a very large molecular size reaching up to 107 109 and degree of polymerization of 3x105 3x106 (Chaplin, 2006). In addition, maltodextrin also produced microcapsules with high water content. This was due to the fact that matodextrin is highly hygroscopic.

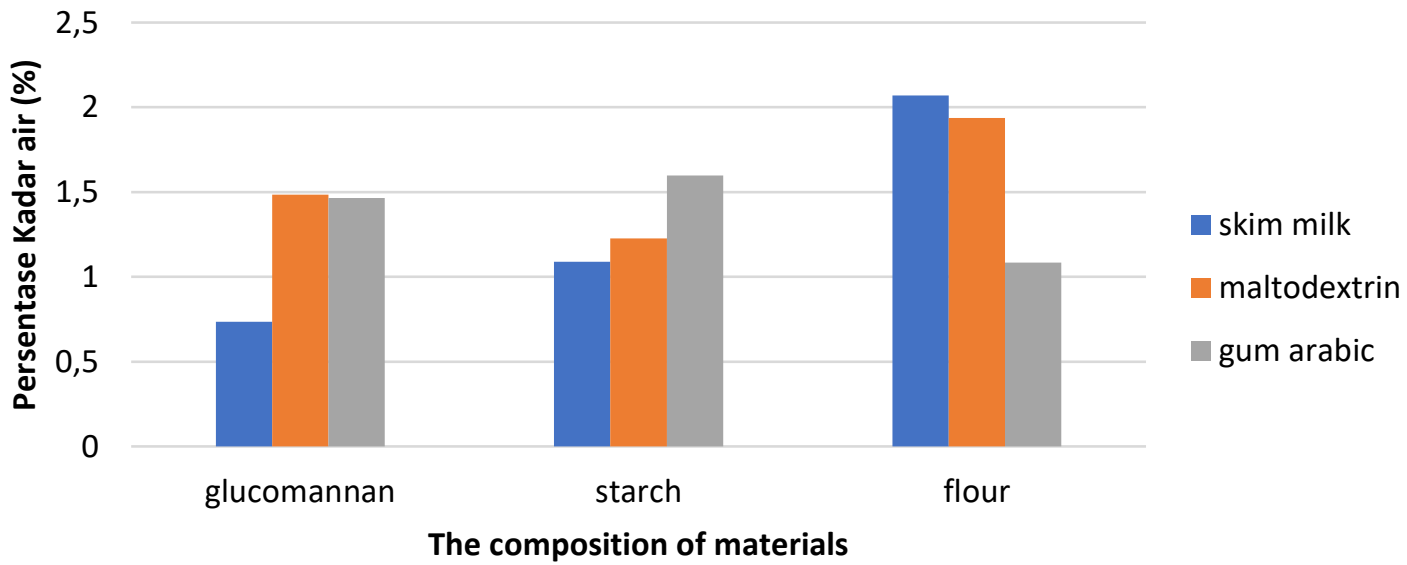

Figure 6. The results of moisture content profile (\%) 


\section{Conclusion}

Based on the experiment performed in MRS media, it can be concluded that the type of iles iles fraction did not have influence on the concentration of lactic acid bacteria, density, water content, yield, and hygroscopisity of the microcapsules. On the other hand, the type of the protecting agent used in encapsulation of synbiotic using spray drying affected the yield of the encapsulation. However, it did not influence the viability of the LAB, density, moisture content, and hygroscopicity. To conclude, based on this study, iles-iles flour and gum Arabic were suggested as the best materials to be used in the encapsulation through spray drying method.

\section{Acknowledgements}

This research was funded by Direktorat Riset dan Pengabdian Masyarakat, Kementrian Riset Teknologi dan Pendidikan No. DIPA.042.06.0.1.401516/2016.

\section{References}

Ansel, C. H. 2004. Kalkulasi Farmasetika Panduan Untuk Apoteker. EGC: Jakarta.

Arifin, M. A. 2001. Pengeringan Kripik Umbi lles-iles Secara Mekanik Untuk Meningkatkan Mutu Keripik Iles-iles. Thesis. Teknologi Pasca Panen. PPS. IPB.

Chaplin, $\quad$ M. $2006 . \quad$ Starch. www.Isbu.ac.uk/starch.htm [6 Maret 2007]

Fritzen-Freire, et al (2013). Effect of microencapsulation on survival of Bifidobacterium BB-12 exposed to simulated gastrointestinal conditions and heat treatments. Food Science and Technology, 50:39-44.

Goldstein, J. 2003. Scanning Electron Microscopy and x-ray Microanalysis.
Kluwer Academic/plenum Publbishers, $689 \mathrm{p}$.

Hermansyah. 1985. Berbagai Macam Penggunaan Temulawak dalam Makanan dan Minuman. Simposium Nasional temulawak UNPAD. Bandung.

Jufri, et al. 2004. Pembuatan Nisosom Berbasis Maltodextrin DE 5-20 dari Pati Singkong majalah kefarmasian vol 1 (1) 34- 46.

Phoungchandang, S. and Sertwasana, A. 2010. Spray-drying of ginger juice and physicochemical properties of ginger powder. Science Asia 36: 40-45.

Takigami, S. (2000), Konjac mannan. In G. O. Phillips, \& P. A. Williams (Eds.), Handbook of hydrocolloids, FL: CRC Press, pp. 413-424.

Tranggono, S., Haryadi, Suparmo, A. Murdiati, S. Sudarmadji, K. Rahayu, S. Naruki, dan M. Astuti. 1991. Bahan Tambahan Makanan (Food Additive). PAU Pangan dan Gizi UGM, Yogyakarta 